\title{
ДО ПИТАННЯ СТВОРЕННЯ ДЕРЖАВНОЇ СИСТЕМИ ІНФОРМАЦІЙНОГО МОНТТОРИНГУ ФАРМАЦЕВТИЧНОГО РИНКУ
}

\author{
Л. Ю. Бабінцева
}

Національна медична академія післядипломної освіти імені П. Л. Шупика

\begin{abstract}
Государственную систему информационного мониторинга фармацевтического рынка предлагается создавать на основе автоматизации процессов управления обеспечения лекарственными средствами за счет использования информационных технологий. Предлагается объединение существующих баз данных и разрабатываемых в интегрированную систему баз данных на основе единых государственных и отраслевых классификаторов.
\end{abstract}

У концепції розвитку фармацевтичної галузі України, що була прийнята на VI Національному з'їзді фармацевтів (2005р.), підкреслена необхідність створення національної політики щодо пріоритетного забезпечення населення лікарськими засобами (ЛЗ), а також впровадження міжнародних стандартів належної виробничої, клінічної, лабораторної, дистриб'юторської, аптечної та інших практик.

Одним із найважливіших напрямів є створення єдиного інформаційного поля у фармації, основне завдання якого полягає в забезпеченні суб'єктів фармацевтичного ринку об'єктивною, оперативною, доказовою та доступною інформацією, що буде сприяти якісному медичному обслуговуванню населення.

Сьогодні в обігу країни знаходяться близько 13,0 тис. найменувань Л3, із них 33,5 \% вітчизняного виробництва, 66,5\%-імпортного. Виробництво ЛЗ здійснюється 141 фармацевтичним підприємством-виробником.

Зрозуміло, що регулювання фармацевтичного ринку неможливе без інформаційного моніторингу шляхом автоматизації процесів управління забезпеченості лікарськими засобами.

Відомості, отримані в результаті нагляду за фармацевтичною діяльністю і контролю над безпекою, ефективністю й якістю ЛЗ, є основою для об'єктивного аналізу ситуації у сфері обігу лікарських засобів.

До державної системи інформаційного моніторингу пропонується включити такі основні показники:

- виключення дублювання введення інформації та підвищення їі достовірності за рахунок ототожнення раніше введеної інформації;

- можливість обміну повідомленнями між територіально розподіленими компонентами;

- підвищення ефективності державного регулювання сфери обігу лікарських засобів;

- забезпечення автоматизованого інформаційного обміну між територіальними органами;

- організація взаємодії з інформаційними системами інших міністерств і відомств у рамках створення електронного уряду.
Функціонування системи повинно грунтуватися на технології функціонування бізнес-процесів, реалізація яких об'єднає в єдине ціле учасників системи, потік робіт, функції та виконавців цих функцій, а також правила управління їх послідовністю. Система $є$ комплексом взаємопов' язаних модулів, кожен з яких має своє функціональне призначення, а також містить необмежену кількість користувачів і структурних одиниць.

Система повинна забезпечити: автоматизацію ведення реєстру ЛЗ, виробів медичного призначення та медичної техніки, дозволених до застосування в Україні; персоніфікований облік призначення пацієнтам ЛЗ у процесі надання медичної допомоги; персоніфікований облік відпуску ЛЗ в аптечній мережі; облік закупівель і раціонального використання лікарських засобів, медичної техніки та виробів медичного призначення на всіх рівнях надання медичної допомоги. Окрім того, має бути автоматизація обліку інформації про побічну дію лікарських засобів; моніторинг цін на лікарські засоби і вироби медичного призначення; моніторинг імпорту/експорту лікарських засобів і виробів медичного призначення.

Для медичних організацій, що здійснюють фармацевтичну діяльність, система дозволить налагодити ефективний облік діяльності організації, надасть можливість своєчасно отримувати та використовувати інформацію про передові досягнення в області фармації. Для населення єдиний інформаційний банк даних системи дозволить надавати кількісну й якісну інформацію про ЛЗ.

Моніторинг цін на лікарські засоби система проводить за видами цін, що включають міжнародні; CIP (іноземні представництва); оптові (оптові фірми); роздрібні (аптечні організаціі).

Інформаційний обмін між компонентами системи повинен здійснюватися за допомогою компонент Сервера об’ єктів в єдину інформаційну систему охорони здоров'я.

Зазначимо, що сервер об' єктів буде виконувати ряд базових функцій і дозволить реалізувати в зв'язці 3

(С) Л. Ю. Бабінцева 
Сервером додатків і Сервером баз даних розподілений збір і зберігання даних медичної інформаційної системи.

Сервер об'єктів повинен мати можливість гнучкого нарощування і змінення структури об'єктів на усіх рівнях ієрархії й автоматичного тиражування змін на потрібні рівні залежно від відповідних налаштувань. Крім того, сервер об'єктів забезпечує унікальну системну (внутрішню) ідентифікацію за усіма рівнями ієрархії для тих об'єктів, для яких це необхідно, і тиражування інформації про всі об'єкти за усіма рівнями ієрархії.

Друга функція - розподілене тиражування конфігурації об'єктів, конфігурації баз даних (групи таблиць для зберігання інформації про об'єкти системи) і самих даних між вузлами системи, об'єднаними в ієрархічну мережу.

Накопичений за останні роки досвід показав, що неможлива взаємодія різних систем за відсутності єдиного стандарту повідомлень, що об'єднує різні системи в єдину розподілену мережу даних. А для забезпечення безперебійної роботи розподілених об’єктів потрібен постійний, стійкий зв' язок між ними, що підтримує технологія серверів повідомлень.
Зрозуміло, щоподібнавзаємодія системи забезпечується за рахунок дотримання єдиних організаційних, методологічнихіпрограмно-технічнихпринципів,насамперед, шляхом уніфікації значень показників, що включаються у відомості про об’єкти обліку, на основі застосування єдиних класифікаторів ідовідників, а такожзастосування для інформаційної взаємодіїз суміжними інформаційними системами єдиних протоколів телекомунікаційних мереж, форм документів і форматів даних, що передаються на електронних носіях. Для всіх учасників інформаційного обміну системи за основу пропонується прийняти єдиний стандарт повідомлень - XML.

Висновки. Створення та впровадження інформаційної системи управління обігом лікарських засобів $\epsilon$ одним із важливих елементів моніторингу та регулювання фармацевтичного сектора охорони здоров'я. Система має забезпечити автоматизацію процесів управління забезпеченості лікарськими засобами, зокрема ведення реєстру лікарських засобів, державних формулярів, приписів тощо; взаємодію 3 різними організаціями, які працюють в галузі охорони здоров'я та за ії межами; облік закупівель і раціональне використання лікарських засобів на всіх рівнях надання медичної допомоги; моніторинг цін тощо. 